\title{
Amila Kasumović, Austrougarska trgovinska politika u Bosni i Hercegovini 1878- 1914, Udruženje za Modernu Historiju, Sarajevo 2016, ss. 397.
}

doi.org/10.14746/bp.2017.24.16

Austrowęgierska obecność w Bośni i Hercegowinie (1878-1918) choć ma swoją bogatą literaturę, nigdy dotychczas nie została zbadana pod kątem polityki handlowej, jaką dualistyczna monarchia prowadziła na Bałkanach. Z tym zadaniem postanowiła zmierzyć się pracownica Wydziału Filozoficznego Uniwersytetu w Sarajewie Amila Kasumović w swojej książce będącej jednocześnie jej dysertacją doktorską Austrougarska trgovinska politika u Bosni i Hercegovini 1878-1914. Praca składa się z pięciu rozdziałów i podsumowania, przy czym w piątym rozdziale autorka omawia statystyki, które następnie podano w formie załączników na końcu książki. Oprócz tego monografia zaopatrzona jest w indeks nazwisk i nazw geograficznych oraz obszerne 9 stronnicowe streszczenie w języku niemieckim a także bibliografię.

Głównym problemem jaki Amila Kasumović postawiła w pracy jest odpowiedź na pytanie, jaki charakter miała austrowęgierska polityka handlowa w Bośni i Hercegowinie? Jak w ciągu niespełna 40. lat sprawowania rządów w Bośni przez Austro-Węgry kształtowały się relacje pomiędzy centrum (Wiedeń, Budapeszt), a peryferiami (Sarajewo)? Warto przy tym podkreślić, że autorka definiuje politykę handlową szerzej, jako zbiory przepisów, zarządzeń, którą można obserwować i oceniać za pomocą statystyki. (s. 12).

Narracja przeprowadzona jest w sposób chronologiczny każdy z pierwszych czterech rozdziałów odpowiada kolejnym okresom tj. od 1878 do 1882, 1883-1895, 1896-1907 i 1908-1914. Podział taki wydaje się być słuszny, gdyż dzięki temu doskonale widać jak zmieniała się polityka handlowa na przestrzeni całego okresu okupacji, aż do wybuchu wojny. Choć decyzja by zakończyć rozważania na dacie rozpoczęcia I wojny światowej nie budzi większych kontrowersji, to jednak we wstępie brakuje wyjaśnienia ze strony autorki dlaczego nie zdecydowała się dalej poprowadzić swoich rozważań. A mogłoby to być bardzo interesujące, zwłaszcza dla osób chcących kontynuować badania nad tą problematyką w okresie I wojny światowej. Zwłaszcza gdyby zdecydował się podać jakieś wskazówki bibliograficzne.

We wstępie autorka obszernie omawia źródła i literaturę, słusznie zwracając uwagę na jednoznacznie negatywną ocenę działań Austro-Węgier w Bośni, zwłaszcza przez historyków starszego pokolenia. Ponadto prezentuje najważniejsze wydarzenia, które jej zdaniem, miały wpływ na kształtowanie się polityki handlowej Austrii w Bośni i Hercegowinie. Są to jej zdaniem, konwencja kwietniowa między Austro-Węgrami a Turcją, która uzależniła Bośnię i Hercegowinę od finansów monarchii, aneksja w 1908 r. a także eksploatacja tych terenów przez mocarstwa, mająca nie tylko charakter polityczny, ale przede wszystkim ekonomiczny. Warto zwrócić uwagę na ten aspekt pracy, gdyż wydaje się on stanowić najsłabszy element całej monografii. O ile autorka sprawnie porusza się w tematach dotyczących relacji na linii WiedeńSarajewo (co widać choćby w kwestii omówienia skomplikowanego prawodaw- 
stwa ${ }^{1}$ ), o tyle niczego lub prawie niczego nie dowiemy się na temat inwestycji prywatnych przedsiębiorców, ani udziału kapitału, zwłaszcza prywatnego spoza Austrii. Tyczy się to zarówno inwestorów z innych krajów koronnych ${ }^{2}$, jak i przemysłowców z Niemiec, Francji czy Wielkiej Brytanii ${ }^{3}$. Z naukowego obowiązku dodam, że ledwie kilka wzmianek dotyczy austriackich i węgierskich przedsiębiorców, wyłącznie jednak w odniesieniu do handlu śliwkami (s. 145-156). Wpływ na to ma zapewne nacisk jaki autorka kładzie na dobór źródeł, pochodzących z archiwów w Austrii i Bośni. Należy pamiętać, że doktorat, obroniony przez autorkę w 2013 r. powstał pod kierunkiem profesora Zijada Šehića związanego z austriackim kręgiem naukowym, co odcisnęło się zarówno na doborze źródeł jak i literatury, która poza kilkoma pozycjami pomija zupełnie dorobek jaki mają w tej kwestii historycy brytyjscy i przede wszystkim niemieccy.

O ile jednak niewystarczającą ilość informacji na temat inwestycji prywatnych można wybaczyć i wytłumaczyć takim, a nie innym doborem materiałów, o tyle zupełnie niezrozumiały jest brak omówienia spraw związanych z eksploatacją bośniackohercegowińskich lasów. Pominięcie tej ważkiej kwestii, kładzie się cieniem na całej monografii, zwłaszcza, że to właśnie drewno stanowiło największe bogactwo kraju, a także główny towar eksportowy ${ }^{4}$. Tajemnicą autorki pozostanie, dlaczego nie zdecydowała się o tym wspomnieć.

Tyle jednak, jeśli idzie o mankamenty omawianej pracy, jakie zauważyłem. Teraz pozytywy. Wspomniałem już o tym, że praca bazuje głównie na źródłach austriackich, a także bośniackohercegowińskich. Choć w tego typu pracy wydaje się to standardem, to jednak warto kilka słów poświęcić kwerendzie, jaką przeprowadziła autorka, gdyż książka w dużej części oparta jest o materiały źródłowe. Zebrane materiały, zarówno z Sarajewa jak i Wiednia stanowią najmocniejszą stronę prezentowanego tytułu. To na ich podstawie autorka dochodzi do wniosku, że polityka handlowa Austro-Węgier w Bośni i Hercegowiny choć posiadała cechy kolonialne (s. 345), nie można traktować jej jako kolonialnego dominium (s. 319). Co więcej za austrowęgierską polityką handlową stało zdecydowanie więcej pobudek natury ekonomicznej niż politycznej. Likwidacja sądów ds. handlu (s. 45-46) będących reliktem z okresu osmańskiego, budowa sieci szkół o profilu handlowym, czy też instytucji takich jak filia węgierskiego centrum handlowego - trgovački muzej (s. 168-175) były inwestycjami,

\footnotetext{
${ }^{1}$ Na który składały się zarówno prawa z okresu osmańskiego, jak i austriackie kodeksy postępowania K. Krysieniel, W cieniu Dayton, Warszawa 2012, s. 99.

${ }^{2}$ Swoje inwestycje w Bośni posiadali zarówno Czesi, jak i Polacy. Zob. Ł. Chimiak, Z dziejów polskiej mniejszości w Bośni. Życie i działalność Wiktora i Artura Burdów, „Studia z Dziejów Rosji i Europy Środkowo-Wschodniej”, t. 48, (2013), s. 70-73.

${ }^{3}$ M. Sparks, The development of Austro-Hungarian Sarajevo, 1878-1918, London-New York 2014, s. $107-119$.

${ }^{4}$ Zob. B. Begović, Razvojni put šumske privrede u Bosni i Hercegovini u periodu austrougarske uprave (1878-1918) sa posebnim osvrtom na eksploataciju šuma i industrijsku preradu drveta, Sarajevo 1978.
} 
które choć wpisywały się w narodową politykę władz, to jednak dawały ogromne korzyści dla miejscowej ludności.

Tym samym autorka odrzuca dotychczasową narrację głównie jugosłowiańskich historyków, którzy jednoznacznie twierdzili, że zarówno Austria, jak i przede wszystkim Węgry czerpały tylko korzyści z eksploatacji Bośni i Hercegowiny nie oferując nic w zamian. Jest to, zdaniem autorki nieprawda, która wynika głównie z faktu, że historycy piszący o okresie 1878-1918 stawiali nacisk na kwestie narodowe i polityczne pomijając dynamiczny rozwój jaki dokonał się w tym kraju za sprawą rządów austro-węgierskich inwestujących bardzo wiele środków w jego rozwój.

Autorce, choć nie udało się uniknąć błędów, należy oddać, że napisała monografię, która stanowi bardzo ważny głos w dyskusji nad rolą Austro-Węgier w Bośni i Hercegowinie w okresie austro-węgierskim. Książka otwiera nowy rozdział, w wydawałoby się, dawno zakończonej dyskusji na ten temat. Tym bardziej że w mojej opinii, jest to praca, którą śmiało można porównać do najlepszych opracowań dot. okupacji Bośni z jakich, jeszcze za czasów Jugosławii, słynęło Sarajewo będące głównym ośrodek badań nad tą problematyką. Nie chodzi tu nawet o samą faktografię, ale sposób w jaki autorka interpretuje wydarzenia $\mathrm{z}$ tego okresu w świetle tego co mogliśmy przeczytać dotychczas. Dlatego monografię Amili Kasumović polecam przede wszystkim, tym którzy chcą spojrzeć z zupełnie innej perspektywy na problem okupacji austrowęgierskiej w Bośni i Hercegowinie.

Tomasz Jacek Lis 